\title{
IMPRENSA E IDEOLOGIA: o jornal Folha de Londrina e os conflitos entre proprietários e trabalhadores rurais em Londrina e região na década de $50^{*}$
}

\section{Humberto Fernandes Nogueira}

Professor de História da Rede Pública Estadual; Especialista em Sociologia e Sociologia da Educação.

A imprensa como empresa capitalista reproduz a ideologia dominante e torna os interesses dessa classe em interesse geral. Este artigo procura analisar o caráter ideológico do jornal Folha de Londrina em relação aos conflitos entre trabalhadores e proprietários rurais de Londrina-PR durante a década de 50.

Palavras-chave: imprensa; jornal; ideologia; anticomunismo; trabalhadores rurais; proprietários rurais.

\section{A IMPRENSA: EMPRESA IDEOLÓGICA}

\section{Imprensa e ideologia}

$\mathbf{T}$ emos o conceito de ideologia segundo a definição de Marx, em que as "idéias da classe dominante são, em todas as épocas, as idéias dominantes" (MARX \& ENGELS, 1982, p.38), a qual, evidentemente, para impor às outras classes as suas idéias, tem que fazer com que a aceitação destas, na média geral, corresponda à ilusão de uma comunidade, ou seja, que todas as classes aspirem a interesses comuns, interesses estes que na realidade são da classe dominante.

No capitalismo, as idéias dominantes são as idéias da burguesia; seus interesses devem aparecer como interesses gerais. É, portanto, no decurso histórico de sua formação enquanto classe dominante, quando ainda não consolidara sua posição dominante no Estado, que a burguesia, ainda como classe revolucionária, conquista e impõe às outras classes seus interesses como interesses gerais. Uma vez detentora do poder político, criando e estruturando o Estado à sua imagem e semelhança, alcança o limite de sua revolução e, portanto, passa a ser a classe conservadora da ordem por ela criada.

A imprensa nasce, no mundo moderno, com a burguesia. O jornalismo no século XIX era a expressão dos confrontos da burguesia contra o Estado absolutista, pela luta do novo contra o velho, pela mudança de realidade, constituindo-se como veículo "realizador de política". ${ }^{1}$

Quando a imprensa se afirma como empresa capitalista e para manter essa posição precisa da venda de anúncios, passa a ligar-se visceralmente às grandes forças econômicas e sociais. Passa então a ser porta-voz de grupos políticos e econômicos que precisam dar objetividade às suas opiniões particularistas. É nesse sentido que a "liberdade de imprensa" impõe-se para a burguesia no seu conjunto, mesmo depois de realizada sua tarefa revolucionária, como bandeira do jornalismo. A fórmula liberal da "liberdade de imprensa" é precisamente dar foro de objetividade aos interesses dos diversos segmentos da burguesia que eventualmente não estejam integrados diretamente ao poder político e de Estado. Sem a "liberdade de imprensa" não há aparência de diversidade de opiniões.

Em tese, o caráter liberal da "liberdade de imprensa" permite inclusive manifestações socialistas nos jornais. Porém, os mecanismos pelos quais a imprensa-empresa atua

\footnotetext{
* O texto é uma adaptação do capítulo 3 da monografia de mesmo nome apresentada como trabalho de conclusão do curso de Especialização em Sociologia e Sociologia da Educação, da UEL, em fevereiro de 1999, sob orientação do professor Pedro Roberto Ferreira.
} 
reproduz a ideologia dominante de forma a neutralizar as vozes destoantes.

As empresas jornalísticas orientadas para a publicidade como maior meio de realização do lucro, faz pressupor o não-questionamento da ordem capitalista, pois, do contrário, de um lado estariam negando a si próprias e, de outro, não teriam chance de sobreviver no mercado, já que nenhuma empresa compraria espaço de anúncio em jornal que questionasse a lógica de seus negócios.

O mecanismo pelo qual os jornais fazem homogeneizar a linguagem e reproduzir a ideologia dominante em suas páginas é o recrutamento dos jornalistas. A empresa contrata os jornalistas segundo sua linha editorial e ideológica, escolhendo os profissionais que se ajustam à sua posição. A possibilidade de que a empresa contrate jornalistas que se oponham à sua linha editorial é pequena. Assim, a atuação do jornalista também passa a ser uma "opção ideológica", ainda que inconsciente. ${ }^{2}$

Segundo MARCONDES FILHO (1986), a notícia é, de fato, a informação manipulada. A manipulação da informação para que esta se apresente ao público valorizada ideologicamente é a regra das redações dos jornais. Esta manipulação não é operada de forma intencional pelos jornalistas, ela acontece na medida em que a própria visão de mundo dos jornalistas está também condicionada ideologicamente, contribuindo em muito para o enviesamento das informações, para a uniformidade do jornal. (MARCONDES FULHO, 1986, p.39)

Para se operacionalizar a ideologia dominante, as notícias devem aparecer no jornal de forma fragmentada, reduzida e desconexa, não existindo interdependência entre os assuntos e os processos sociais reais, tais como se apresentam em variadas seções como economia, política, lazer, cultura, sociedade, etc., quebrando as possibilidades de unidade do mundo real.

Da mesma forma, a definição do que é útil como notícia parte de premissas ideológicas, tanto quanto o enfoque dado a ela, o tamanho e a distribuição no jornal, chegando até mesmo à sonegação de informações, sendo que a prática da sonegação é intervenção consciente dos editores.

\section{Breve histórico sobre a Folha de Londrina}

O jornal Folha de Londrina foi fundado em 29 de outubro de 1947 por João Milanez e, embora existissem diversas dificuldades para a produção e distribuição do jornal, com características ainda artesanais, a lógica da Folha de Londrina foi, desde sua fundação, empresarial. ${ }^{3}$

Nos primeiros anos, até 1952, a Folha de Londrina teve três chefes de redação: Moacir Arcoverde, Rafael Lamastra e A. Damasceno da Silva. Desse ano até 1965, o chefe de redação foi Nilson Rímoli.

O jornal foi semanal até esse mesmo ano, o que não impedia a avidez de seu proprietário em torná-lo uma empresa muito lucrativa. A venda de anúncios sempre foi o principal objetivo do jornal, quase chegando a provar na prática que, "Teoricamente, o tamanho ideal da parte noticiosa é para o editor (de forma diferente do que para o leitor), igual a zero". (COLETIVO DE AUTORES "IMPRENSA", 1984, p.62)

Assim lembra João Milanez:

"Como semanário, a Folha chegou a tirar uma enormidade para a época - 4.500 exemplares, dos quais 3.000 para assinantes. Tirava edições especiais de fim de ano, 7 de setembro, aniversário da cidade. Uma dessas edições chegou a ter 28 páginas - 27 de anúncios." (TRIGUEIROS FILHO \& TRIGUEIROS NETO, 1991, p.45)

Em 1956 o jornal tornava-se o segundo no Paraná a possuir uma impressora "rotativa" e, de um caderno diário de dez a doze páginas, passava a publicar, desde então, dois cadernos diários de oito páginas cada, chegando a publicar, nas "datas comemorativas", quatro ou cinco cadernos de oito páginas.

A Folha de Londrina tinha um padrão estético moderno, comparável aos grandes jornais de circulação da época, sempre buscando ser bastante atraente ao público leitor.

Em 1954, a Folha instalou seu primeiro receptor radiotelegráfico. Até então, o jornal conseguia as notícias nacionais através de rádio-escuta.

A contratação dos serviços de agências noticiosas representou enorme progresso para a vida do jornal, que tinha que competir com os grandes jornais de São Paulo. O aeroporto da cidade mantinha sete vôos diários para essa capital e trazia jornais que podiam ser lidos no dia da publicação.

O crescimento do jornal está ligado ao fato de ele publicar notícias e anúncios locais e regionais, caracterizando-se por uma linha editorial "moralista e conservadora", empenhada em projetar a imagem da cidade de Londrina como "cidade progresso", mostrando-se preocupado com a afirmação de uma "pomposa vida social". ${ }^{4}$

Assim, o jornal Folha de Londrina firmava-se desde os primeiros tempos, conseguindo crescer e circular até hoje ininterruptamente, como porta-voz dos interesses da classe dominante local, e ninguém melhor do que Walmor Macarini, um dos diretores de redação do jornal, para dizer a receita do sucesso dessa empresa:

"Porque os poderosos, em verdade, estavam noutra. Queriam mesmo eram (sic) curtir o dinheiro que, honestamente, ganhavam (tudo era honesto naquele tempo), curtir suas amantes; preservar, é verdade, sua vida familiar (e para isto cuidaram de também construir o Country Club). Os jornalistas conviviam bem com eles, eles conviviam bem com os jornalistas. Nós escrevíamos a história de seus sucessos, eles escreviam a história dos jornais. Porque, sem essa gente tão diferente que aqui aportou, o jornalismo não teria frutificado.

"No que respeita a nós da 'Folha de Londrina', que é o jornal onde só e sempre trabalhei, acho que aprendemos a falar a linguagem dos homens desta terra. Se tivemos sucesso, foi por isto." (apud TRIGUEIROS FILHO \& TRIGUEIROS NETO, 1991, p.66)

Rev. Mediações, Londrina, v. 4, n. 2, p. 7-18, jul./dez. 1999 


\section{IMPRENSA E IDEOLOGIA: O JORNAL FOLHA DE LONDRINA E OS CONFLITOS NO CAMPO}

\section{Um jornal anticomunista}

A linguagem do jornal nos anos 50, embora não procurasse ter a entonação sensacionalista que existia em vários jornais, particularmente com relação aos conflitos de classes aqui discutidos, elaborava um discurso virulento e incorporava os elementos da imprensa notadamente sensacionalista.

A Folha de Londrina incorporava os interesses da classe dominante local e deveria ganhar bastante com isso, pois além de garantir a venda de anúncios fazia das notícias sobre esses conflitos uma das grandes mercadorias vendida aos leitores.

Sensacionalizar a notícia deve ter ajudado muito a Folha de Londrina a efetivar seus lucros. Nesse sentido, Ciro Marcondes Filho faz esta reflexão:

"Para mim, a aparência de valor de uso no jornalismo leva-o necessariamente a 'sensacionalizar' a vida política, econômica e social de determinada formação histórica. O que caracteriza o jornalismo não é somente vender os fatos e acontecimentos (que seriam puramente o valor de uso da informação), mas, ao transformá-los em mercadoria, explorar e vender a sua aparência, o seu impacto, o caráter explosivo associado ao fato. Isso constrói a sua 'aparência de valor de uso'." (MARCONDES FILHO, 1986, p.30)

O jornal, assim respaldado por certa credibilidade, tornava-se instrumento de divulgação da "trama" de uma suposta conspiração.

Segundo o jornalista Nilson Lage, a notícia é axiomática. A responsabilidade que o jornal se arroga sobre o testemunho do fato dispensa a crítica. Para ele, os juízos de valor, bem como seus componentes ideológicos, são reduzidos como evidência, "impõem-se como dados", e a evidência é "incontestável" para os leitores:

"O importante é compreendermos que, diante de uma proposição dada como verdadeira, no contexto de um sistema de relações de poder socialmente instituído, o receptor fará qualquer operação possível no universo do seu sistema de apreensão lingüístico (em suma, recorrerá aos instrumentos adequados da competência lingüística) para que a proposição não seja desmentida. Isto não significa que tenha percebido o real sentido da proposição, ou o sentido que se quis atribuir". (LAGE, 1979, p.42-43)

A partir da notícia narrada assim, de forma sensacionalista e articulando proposições ideológicas que lhe interessasse, dava a idéia aos leitores de que existiria uma cons- piração, que vinha sempre associada a um plano sinistro de dominação internacional cuja origem estava na Rússia.

Essa idéia de conspiração era sistematicamente veiculada pelo jornal, conspiração envolta em uma atmosfera de segredo, onde a hierarquia se apresentava na forma de uma pirâmide, na qual cada homem teria um grau de responsabilidade, sendo que, na base, figuravam aqueles de menor expressão, porém não menos importantes para a execução de planos sinistros.

Para que a idéia de conspiração comunista permanecesse envolvendo os leitores, o jornal procurava não "materializar os personagens". Sempre falava na existência dos "agentes do credo vermelho", porém eles somente eram nominados quando fosse impossível omiti-los - na abertura de um inquérito ou quando tinham um afastamento da convivência cotidiana da comunidade local (os grandes chefes) como Luís Carlos Prestes, entre outros. Em nenhum momento na década de 50 foi publicado na Folha de Londrina qualquer artigo ou entrevista de qualquer comunista declarado ou que assim o jornal tivesse qualificado.

Essa forma de construir o discurso pretendia criar uma sensação de "desconfiança" nos leitores a respeito de pessoas da vida cotidiana. Essa técnica jornalística foi frequientemente utilizada em Estados autoritários, segundo MARCONDES FILHO (1986, p.17):

"Em situações conjunturais de recrudescimento das forças autoritárias de dominação, a intimidação dos indivíduos passa a ser uma técnica cotidiana. No período nazista, esta técnica foi amplamente aplicada. Sua função era a de criar confiança no governo (BRAMSTEDT, 1946, p.164-5). No pós-guerra, particularmente caracterizado pela polarização da guerra fria, o inimigo público perdeu sua conotação estereotipada dos inimigos do Estado fascista, como o 'judeu usuário' e o ‘comunista ateu'. O 'inimigo' deixou de ter contornos fixos e, conforme a propaganda da guerra fria, 'já vive junto de nós' (FUNK WEKENTIN, 1977, p.190 et seqs.). Essa disseminação de 'inimigos públicos' por intermédio dos meios de comunicação 'de massa' viabilizados pela adoção de estereótipos e da confirmação, na maioria dos casos, de marginalizações reais da estrutura econômica, política e social, atua no sentido de quebrar possíveis laços de solidariedade e união, que, num segundo momento, poderiam ser mobilizados contra o Estado".

Ao invés de publicar o teor dos discursos dos que eram qualificados de comunistas, o jornal, quando muito, interpretava-os, filtrando os conteúdos e retendo a sua essência.

Para o jornal e seus colaboradores, a "conspiração comunista" estendia seus tentáculos em todas as direções, por todas as instituições da sociedade, encobrindo-se nas aparências de uma simples sociedade beneficente:

"A bandiocracia comunista, a repelente escravocracia soviética, essa mesma que massacra os húngaros e não thes permite, ao menos o direito de fugir do in- 
ferno vermelho, encontra, em tôda parte uma esplêndida facilidade de penetração. Os argumentos de que lança mão, a hipocrisia como tática, o disfarce, a máscara, como instrumentos, insinuantes, coleantes, envolventes, vão roendo as resistências e adormecendo tôdas as vigilâncias, mesmo as eternas.

"As chamadas 'linhas auxiliares', 'frentes legais' etc., pululam por tôda parte, encarapuçadas em sociedades beneficentes, clubes, escolas de alfabetização de adultos". (LUZ, 1956a, p5.)

A contrapartida à suposta conspiração comunista seria a invocação de forças sociais para uma verdadeira "santa aliança", entrecruzando-se política e religiosidade nas páginas do jornal. Para a Folha de Londrina, era necessário travar uma "cruzada cristã anticomunista", que recrutaria gente de fé e disposta a levantar uma bandeira exemplar:

"Agora, pensem bem nesta pergunta: em nome de quê vamos combater o comunismo? (...) A civilização cristã, senhor, dirão vocês. (...) Aí vocês dirão que entendiam que a luta seria pela conservação do que aí está, isto é, uma luta defensiva (...) A esta altura, pergunto, outra vez: mas vocês não viram que, realmente, isto que aí está, como ordem política, está longe de ser a realização prática do cristianismo? (...) Vêm exemplos dignificantes de renúncia? Vêm o recato nas jovens cristãs? (...) Que diz você pai? Que diz a senhora, mãe? Que dizem vocês todos? É com essa bandeira que nós vamos lutar contra o comunismo? É com ela que vamos arrastar as multidões famintas e angustiadas para o nosso lado? Pode-se conseguir os aplausos dos esquálidos da miséria, dos desesperados roídos de vinganças sonhadas, em cujas almas levantam-se como monstros do apocalipse, levados pela terrível doutrinação de ódio dos comunistas, a Inveja, a Cólera, todos os defeitos que nós conhecemos (somos cristãos, pois não?) como pecados capitais?”. (LUZ, 1956b, p.5.)

Este exemplo de discurso anticomunista eivado de moralidade cristã, opondo cristianismo a comunismo, mostrando a idéia de que a miséria estaria em contraposição a uma realização de civilização cristã, integrava-se ao discurso de Juscelino Kubitschek, segundo CARDOSO (1978, p.251-252):

"Da perspectiva ideológico-política, tanto quanto da perspectiva ideológico-religiosa encontra-se razões das mais relevantes para o combate ao subdesenvolvimento. Da primeira, como preservação da liberdade e da democracia, que se vêem ameaçadas pela existência generalizada da miséria; da segunda, pela necessidade de valorização do homem. 'Somos e desejamos continuar uma nação cristã.... Ser uma nação cristã nos dias que correm é considerar a injustiça social o que ela é realmente, um grande pecado contra Cristo. Não é cristã a nação indiferente à miséria, ao subdesenvolvimento com todo o seu cor- tejo de horrores.' 59 'Nossa política de índole essencialmente cristã recebe do homem o seu impulso e vê no homem a sua finalidade. ${ }^{60} \mathrm{O}$ estado de pobreza não permite ao homem a sua afirmação integral, os princípios de justiça social não resistem diante da miséria continuada. É preciso vencer o subdesenvolvimento para resguardar o humanismo.

"Também no campo moral, como vemos, se buscam argumentos capazes de sustentar a política desenvolvimentista e eles parecem ser, no plano explícito da ideologia, os mais fundamentais. Em geral eles aparecem no discurso de uma forma positiva, através da afirmação dos princípios cristãos, e de uma forma negativa, através destes mesmos princípios como anticomunismo, cujo significado aparece como idêntico a antimaterialismo."

\section{A Folha de Londrina e a representação dos conflitos no campo}

A Folha de Londrina transformava o $1^{\circ}$ de maio em "festejo cívico" no qual que o "homenageado"(trabalhadores ou lideranças sindicais) não podia falar, apenas ouvir sobre suas qualidades e perspectivas de futuro. $\mathrm{O}$ trabalhador exemplar, nos discursos do jornal, deveria ser dócil, dedicado, responsável, disciplinado e submisso às leis e à hierarquia social.

Quando da aprovação, em maio de 1955, da lei de criação do Serviço Social Rural, que deveria fornecer assistência técnica, serviço social e estímulo à criação de cooperativas no meio rural (CRUZ et al, 1983, p.200), foram feitas, pelo jornal, várias críticas aos seus elaboradores. (BORBA, 1955, p.8)

A Folha de Londrina dizia que a maior dificuldade em promover a seguridade social para os trabalhadores rurais era sua característica "nômade", pois que não permanecia fixo em determinado local de trabalho como o trabalhador urbano.

Em maio de 1956, sobre a possível aprovação pelo Congresso do aumento do salário mínimo, o jornal se pronunciava:

"Que ninguém se iluda: se a mão de obra para a lavoura está difícil agora, imaginemos, quando o salário mínimo subir, a debandada que se dará das roças para os grandes centros, pois o trabalhador rural não vai querer saber se os produtores podem ou não pagar salários mais altos: se podem podem, se não, êle apanha as tralhas e vai engrossar a demografia das cidades.

"Cá entre nós, a situação não anda boa e nem o mais ingênuo dos patrícios pode deixar de senti-lo. Oferecer solução para o problema não o fazemos porque, como já disseram, um dos nossos grandes males reside no fato de que já há muita gente a apregoar soluções. Ficamos à espera daquela fórmula milagrosa. Afinal, não há mal que sempre dure. E o nosso vem de longe...”. (A FÓRMULA..., 1956, p.1) 
Para o jornal, uma das causas do êxodo rural seria justamente o aumento das despesas com a mão-de-obra, porém, não porque o fazendeiro despedisse o trabalhador, mas porque este último, mal agradecido, estaria deixando o "produtor" solitário, abandonado. O trabalhador rural, para a Folha de Londrina, deixava o meio rural de livre e espontânea vontade.

A campanha anticomunista tomou grandes proporções no jornal a partir de 1956, em razão de uma maior organização do Sindicato dos Colonos e Assalariados Agrícolas de Londrina. A organização deste sindicato não obedecia ao "bom modelo" representado pelo jornal, criando, dessa forma, problemas de ordem pública. Contra a "conspiração comunista" seria necessário, para a Folha de Londrina, que os "homens de bem" se unissem para uma cruzada sem precedentes, que trouxesse de volta a paz e a tranquiilidade para uma sociedade enganada e corrompida pelos "agentes da desordem".

A Folha de Londrina cedia espaço para os "homens de bem" que quisessem restabelecer a ordem e ingressava junto a eles na cruzada, transformando-se em veículo privilegiado da manipulação das informações em famigeradas notícias de denúncias a algum "mal" iminente.

O marco inicial de uma campanha jornalística sistemática em torno de uma "ameaça comunista" nos meios rurais da região foi um manifesto dos proprietários rurais entregue ao delegado de polícia publicado com o título "Denúncia da lavoura contra a articulação comunista em Londrina", em 19 de maio de 1956:

"Os cidadãos que se subscrevem, nomeados por um grupo de lavradores, na noite de ontem, dia 17, para promover medidas acauteladoras de seus interêsses e da ordem pública, junto às autoridades competentes, têm a honra de passar às mãos de vossa senhoria os pontos que julgam necessários para que se detenha, sem perda de tempo, o vasto movimento comunista em plena articulação nesta zona, sob pretexto de sindicalização da lavoura e reclamando favores não previstos em leis ou contratos conhecidos. Intensifica-se sobremodo, sem temor de êrro ou engano, êsse movimento de caráter sedicioso entre nós. $E$ as pessoas que se acham à frente de tais reuniões são notória e publicamente filiados ao extinto Partido Comunista do Brasil. Por conseguinte, é intolerável a ação desses elementos que, sob falso pretexto, continuam agindo, na sua tarefa de fomentar sinazia e discórdia entre classes trabalhadoras. (...) dentro do qual encontram campo fácil as convulsões sociais necessárias para a implantação do regime comunista". (DENÚNCIA DA LAVOURA..., 1956, p.1)

Nesse texto, o sindicato aparece como instrumento de atuação dos comunistas. A organização dos trabalhadores rurais estaria sendo manipulada por agentes do PCB, e se "nem mesmo na Rússia Soviética" existiam tantos direitos aos trabalhadores, a reivindicação destes, no Brasil, só poderia estar ligada a desejos de provocar desordens, prejuízos, confusões, insegurança, de modo a implantar o regime comunista no país.
A Folha de Londrina procurava demonstrar um sentimento de indignação dos proprietários rurais, que deveria ser incorporado por toda a sociedade local.

Dessa forma a Folha de Londrina começava a divulgar alguns nomes até então "não revelados", que seriam comunistas fichados, como o caso do militante do PCB Manoel Jacinto Corrêa e do advogado Flávio Ribeiro, que prestava assessoria jurídica ao sindicato. O jornal começou a classificá-los como "chefes do bolchevismo local", e o "submundo" onde tramavam e conspiravam eram o edifício Autolon e Cine Marabá. Esses locais passariam, a partir de então, a sofrer constantes intervenções pelas autoridades públicas, marcando ainda mais o papel da polícia contra os comunistas.

Considerando-se a idéia de que a organização dos trabalhadores seria manipulada por comunistas e estes eram identificados como criminosos e subversivos, passar-se-ia a combatê-la como se ela fosse prejudicial a toda sociedade. O jornal mostrava-se então empenhado no combate ao Sindicato dos Colonos e Assalariados Agrícolas, tornando-se um dos "carros-chefes" da "cruzada anticomunista". Porém, demonstrava sua incapacidade de inserção direta no meio dos trabalhadores rurais e indicava que todos os esforços tinham que ser tomados por outras vias de comunicação e acesso àquelas populações por parte dos homens públicos e proprietários rurais da região.

Toda esta movimentação contrária ao Sindicato dos Colonos e Assalariados Agrícolas é compreensível. Um confronto entre trabalhadores e proprietários acarretaria enormes prejuízos à classe patronal, já que era época da colheita de café. (ARGUS, 1956, p.10)

No dia 20 de maio de 1956, o colunista Argus inseria uma nota em sua coluna comentando o resultado da denúncia dos proprietários rurais entregue ao delegado de polícia.

Dizia o colunista que o Cine Marabá havia sido interditado por uma diligência chefiada pelo delegado e que em suas dependências teria sido encontrado "farto material" sobre atividades comunistas nos meios rurais. Dizia ainda que os "vermelhos" estavam procedendo a completo levantamento da situação dos colonos em todo o norte do Paraná para levá-los a um movimento de sindicalização "cujos verdadeiros objetivos se desconhecia". Informava também que o material teria sido enviado para o D'OPS em Curitiba.

É interessante notar que a interdição de um cinema, a devassa em arquivos não era considerado apenas normal mas era também legitimada e incentivada, na maioria das vezes, pelo periódico. Estava aberta a "temporada de caça aos comunistas".

Poucos dias depois era convocada, através de uma carta ao jornal, por um grupo de proprietários intitulados Comissão Organizadora da Resistência à Propaganda da Mentira, uma reunião com os proprietários da região para a contra-ofensiva aos comunistas.

O texto dizia que além das grandes dificuldades sofridas pelos proprietários, do seu "destino heróico" depois de tantas "batalhas" contra os fenômenos da natureza para o cultivo da terra, deviam ainda unir forças para combater o "mal" que se aproximava de maneira avassaladora.

Com apelos aos sentimentos "humanos" e "cristãos" daqueles que "paternalmente" tudo faziam para o bem dos 
trabalhadores, falava do "perigo vermelho" que tentava transformar as relações de democracia e liberdade nas de "violência e escravidão russa".

No dia 22 de maio de 1956, o vereador Rafael Lamastra comentava a "batida" no Cine Marabá e dizia que os comunistas teriam se posto a salvo das malhas da lei.

Ele conclamava o inspetor do Trabalho de Londrina a fazer um trabalho de conscientização de direitos e deveres junto aos trabalhadores rurais, alertando-os das "falsas promessas dos comunistas".

Nesse apelo ao Ministério Público, o colunista e vereador caracterizava os trabalhadores rurais como enganados e ludibriados pelos comunistas. Os exploradores dos trabalhadores rurais seriam os comunistas e não os fazendeiros.

Tinha-se a preocupação de demonstrar a necessidade de levar a propaganda anticomunista em todos os recantos onde estivessem os trabalhadores rurais:

“Ainda mais, está o Ministério do Trabalho na obrigação de se dirigir, diretamente, aos focos subversivos e prestar assistência aos homens do campo ludibriados e explorados. Para isso, conclamamos o sr. Helvécio Brandão, que é o Inspetor sediado em Londrina, a que ponha mais uma vez à prova o seus espírito público e funcional, jogando "fogo de encontro" às atividades comunistas e esclarecendo aos assalariados campesinos sôbre os seus direitos e deveres.

"Paralelamente com essa orientação do Ministério do Trabalho, devem os membros da Comissão Organizadora da Resistência à Propaganda da Mentira conjugada com os Partidos centristas, encetar uma campanha intensa de esclarecimento, percorrendo as fazendas, patrimônios, vilas, distritos e municípios do norte do Paraná, para evitar que consequiências desastrosas advenham do trabalho de solapamento das instituições, pregado abertamente pelos adeptos do credo 'vermelho"'. (LAMASTRA, 1956, p.4)

Em nível nacional, foi encaminhado ao Congresso, aos ministérios e ao presidente da República pedido de ajuda "contra os comunistas", graças à gravidade que representava o sindicato para os proprietários rurais da região.

A maior liderança dos proprietários rurais da região era o Sr. Álvaro Godoi. Impulsionador das campanhas anticomunistas, eloqüente orador e com uma respeitabilidade muito grande entre os membros de sua classe e de bastante projeção local, tomava as rédeas do combate ao movimento dos trabalhadores rurais. Tinha um programa na Rádio Londrina (uma estação local) em que comentava e divulgava as atividades da Associação Rural de Londrina, entidade patronal.

Com discurso austero de defensor dos cafeicultores do norte do Paraná, ganhou toda uma aura de desbravador e pioneiro, como um "homem que obteve sucesso pelas mãos calejadas pela labuta", "embrenhando-se na mata virgem e fazendo brotar a riqueza da terra".

Moralista, conservador e intransigente no que diz respeito aos interesses de sua classe, seu nome estava sempre ligado à cultura do café, principal fonte econômica do município naquela década. Com toda a autoridade que a imprensa lhe conferia, como o "trabalhador vencedor", não admitia questionamentos quanto à justeza das práticas de seus companheiros de classe.

Era o líder da Comissão Organizadora da Resistência à Propaganda da Mentira e fez discurso na Câmara dos Vereadores, conseguindo aprovar o envio de um telegrama ao presidente da República, ao ministro da Justiça, ao governador do estado, ao secretário do Interior e Justiça ao chefe de polícia e à Assembléia Legislativa do Paraná pedindo ajuda no combate ao comunismo na região (NOVAS DENÚNCIAS..., 1956, p.1-10):

\begin{abstract}
"A Associação Rural de Londrina, reunida com os representantes da associação Paranaense de Cafeicultores, FARESP e Associação Rural Brasileira, leva ao conhecimento de v.excia. que elementos agitadores, comunistas fichados, estão promovendo agitação no meio rural do norte do Paraná, paralisando os serviços das fazendas atirando colonos contra patrões e trazendo desassocêgo(sic) à lavoura, com falsas promessas. Há grande perigo de choques, de consequiências imprevistas, justamente em momento de plena colheita de cereais, cuja produção corre o risco de perder-se, concorrendo para o encarecimento da vida e grande prejuízo à classe rural. Pedimos urgentes providências contra os agitadores, pois não cabe culpa aos colonos que estão sendo enganados." (GODOI, 1956a, p.4)
\end{abstract}

Fazia-se uma imagem apocalíptica de uma organização de trabalhadores, insuflada pelos agentes "vermelhos" com objetivos de um caos na economia da região e do país, para enfim tomarem o poder.

O telegrama indica dois objetivos. O primeiro, de pedido de ajuda ao Estado para reprimir o movimento. $\mathrm{O}$ segundo era o de adiantarem-se às possibilidades diretas de repressão por parte dos proprietários, legitimando-os para possíveis práticas violentas de coerção. É significativo, no discurso de Álvaro Godoi, o alerta de que poderia haver "choques de conseqüências imprevistas".

Aqui, a exemplo da maioria dos artigos, editoriais e notícias da Folha de Londrina, os trabalhadores rurais eram considerados massa amorfa, conduzidos pelos agentes subversivos.

O telegrama aprovado na Câmara dos Vereadores teve repercussão na Câmara dos Deputados no dia 12 de julho de 1956, quando o deputado Hugo Cabral, da UDN-PR, que fora prefeito de Londrina de 1947 a 1951, fez a sua leitura após avalizar seu conteúdo diante do plenário. (DISCORRE NA CÂMARA..., 1956, p.1)

O mesmo deputado volta a insistir na Câmara dos Deputados com o mesmo teor do telegrama e outros manifestos de proprietários rurais acerca do grave "perigo comunista", referindo-se a Londrina como "sede do estado maior comunista no norte do Paraná":

"Recebi, recentemente de Londrina, sede do estado maior comunista no norte do Paraná, uma carta do 
meu velho e querido amigo sr. Álvaro Godoi, datada de 27 de junho último, em que êsse grande pioneiro do desbravamento da zona de Londrina, onde entrou e se estabeleceu há 26 anos, me descreve a desordem, o desrespeito e a indisciplina existentes nos estabelecimentos agrícolas daquela região. (...) Senhor presidente: Em nome dos agricultores do Norte do Paraná, eu dirijo nesta oportunidade um veemente e sincero apêlo às mais altas autoridades dêste País, no sentido de pôr côbro, de uma vez por tôdas, à criminosa agitação que os inimigos do regime democrático e cristão, sob a qual temos vivido, organizaram e estão procurando desenvolver cada vez mais no Norte do Paraná." (CABRAL, 1956, p.5)

Em certo momento, o discurso dos proprietários rurais voltava a enfatizar as críticas ao governo pela situação da lavoura e a infiltração comunista. Num discurso de Álvaro Godoi proferido na Rádio Londrina e publicado na íntegra pela Folha de Londrina, o representante dos proprietários fazia uma análise do "quadro geral" da lavoura cafeeira, comentando que a causa principal das agitações comunistas seria as injustiças do governo para com a classe dos proprietários rurais, mostrando-se intransigente na "luta" pelo que considerava pertencer a eles: o "fruto de seu trabalho".

Nesse discurso, dizia não reconhecer a mediação de um sindicato tido como comunista e representava os patrões como "explorados e injustiçados", "sendo arrastados para os Tribunais, como criminosos vulgares". (GODOI, 1956b, p.4)

Os proprietários rurais autodenominavam-se trabalhadores e consideravam-se explorados pelo governo, razão pela qual não podiam pagar mais aos seus subordinados. Procuravam demonstrar que eram os proprietários que lutavam por justiça, exigindo aquilo a que tinham direito: "o fruto do seu trabalho". Portanto, os "contratos" com os trabalhadores eram determinados pelo nível de "pobreza" dos patrões.

As críticas dos cafeicultores à política econômica, no que diz respeito à agricultura, estava relacionada diretamente ao confisco cambial, único item, aliás, a pesar sobre seus lucros. Embora o governo Juscelino Kubitschek não desse prioridade à agricultura, os cafeicultores eram amparados em "bônus pagos aos exportadores" (SKIDMORE, 1982, p.209-210), bem como através de tentativas de não deixar declinar os preços do café no mercado internacional. Mesmo assim, os cafeicultores insistiam no fim do confisco cambial. A Sociedade Rural Brasileira, assim como diversas entidades regionais, a exemplo da Associação Rural de Londrina, ameaçavam, diante deste confisco e das pressões que sentiam por parte dos trabalhadores rurais, realizar uma "marcha da produção", que levaria uma grande concentração de proprietários rurais de vários estados brasileiros a protestarem no Rio de Janeiro. (CAMARGO, 1983, p.158)

Com a legitimação do discurso através da representação de uma "exploração" a que estariam submetidos os proprietários rurais, buscava-se demonstrar autoridade para que estes escolhessem como proceder nos contratos com seus subordinados. A escolha, é claro, seria aquela em que não se interpusessem obstáculos à realização de justiça idealizada pelos proprietários, e, para que isso acontecesse, não reco- nheciam mediadores como o Sindicato dos Colonos e Assalariados Agrícolas - que não teria autoridade por ser guiado por comunistas. Para Álvaro Godoi, ninguém teria maior interesse pelos anseios dos seus subordinados do que seus próprios patrões, que seriam honestos e trabalhadores, tanto quanto aqueles.

A ameaça de demissão em massa tentava passar um sentimento de insegurança ainda maior, caso os trabalhadores rurais não cooperassem na resolução do "problema" de conformidade com a classe "justa e honesta". Sendo uma classe de justos, era vergonhoso que tão abusados insufladores da desordem questionassem ou "vulgarizassem" a autoridade de sua classe.

Os proprietários rurais mostravam-se, através da Folha de Londrina, como trabalhadores honestos e acima de qualquer suspeita, não podendo responder à justiça institucional - estavam acima da "Justiça" e das "instituições".

Assim, os colonos eram representados como ingratos, fruto do ardiloso plano de catequização de perversas "doutrinas moscovitas". Álvaro Godoi chegava a invocar o respeito aos mais velhos aos colonos que se "revelavam" por efeito das "más influências".

O final do discurso de Álvaro Godoi remetia à organização dos proprietários em torno de uma associação, que resistiria ao mal de que estariam sendo ameaçados, e à necessidade de recrutar mais combatentes.

A analogia que se fazia a uma "cruzada" simbolizava a retomada da "paz" e da tranqüilidade pelas almas pacíficas dos colonos atormentados por comunistas - "homens sem Deus", desonestos; somente uma "guerra" realizada em nome da verdade e conduzida pelos "soldados da produção" triunfaria sobre os "infiéis" e "traidores".

Editoriais muitas vezes apelativos demonstram uma sede tão grande de legitimar a repressão às chamadas "ações comunistas", que, em nome da defesa do "Estado de direito" e suas instituições, insinuavam práticas coercitivas que questionavam o próprio Estado de direito que defendiam.

Sem explicitar minimamente quais eram as "perversidades" supostamente ensejadas pelos "comunistas", cobravam das autoridades, a qualquer custo, provas que incriminassem os dirigentes do Sindicato dos Colonos e Assalariados Agrícolas:

"Segundo o informante, as brechas que a ação desses profissionais do engôdo têm aberto entre fazendeiros e colonos são muito mais graves do que se calcula. É que de nada adianta recorrer às autoridades, pois - pasmem os leitores! — ouvi dizer de alta personalidade do Estado, a quem está afeta a questão, que não pode agir sem provas! Pois se não tem provas, que as procure, faça inquérito, investigue, porque os fatos aí estão, berrantes e aberrantes, entrando pelos olhos adentro, e só não vê quem não os queira ver. "A agitação que lavra nos meios rurais, buscando tão só desunir o organismo produtor agrícola, envolve profundas e inquietantes consequiências para a própria vida nacional, pois, setores dos mais importantes, estão sendo abalados pelo trabalho solerte dos agentes da insídia e da traição. 
"A questão já não mais se restringe ao círculo das relações particulares entre fazendeiro e colono. Dilargou-se pela planície ampla dos grandes e impostergáveis interêsses do país, e pode fazer periclitar as próprias instituições. A infiltração comunista em todos os campos da atividade brasileira já se tornou um fato. Com a sua extensão aos meios rurais, agora, a questão assume proporções alarmantes. Só não a percebe quem se prove -upinamente (sic) ingênuo para admitir como verdadeiros os propósitos dêsses elementos. E o pior cego é o que não quer ver." (A AGITAÇÃO..., 1956, p.1)

A Folha de Londrina girava em torno de abstrações a respeito de "planos" e articulações dos comunistas para o "caos social". No entanto, em nenhum momento conseguia documentar as supostas atividades subversivas, tampouco seus colaboradores e principais interessados, os proprietários rurais, conseguiram provas de ilícitos. Nessa carência de legitimação do discurso com "provas incontestes", atribuía ao Estado a responsabilidade pela falta de provas que pudessem incriminar os supostos comunistas e colocá-los "fora de circulação".

Podemos observar, então, que o jornal acabava deixando nas entrelinhas seu conceito de democracia, conceito que se tornava mais explícito no editorial, alguns dias depois, onde simplesmente condenava movimentos sociais que propusessem transformações sociais:

“A propósito de atividade de agentes comunistas que, a pretexto de promover sindicalização do trabalhador rural, estão implantando a desordem e a anarquia entre colonos da região, ouvem-se a cada passo, comentários de todos os tipos. Amiúde observam-se frases ou expressões assim: 'A Constituição garante o direito de reunião'... 'O direito de associação é assegurado pela Constituição' ... 'Estamos num regime democrático ou não estamos ?"...

"Vêm-nos à mente, daí, certas considerações de ordem filosófica que valem ser repetidas.

"Ninguém ignora nem desmente a verdade que ha naquelas frases. Sim, de fato, a Constituição garante o direito de reunião e de associação; a democracia é um regime de liberdade e nêle é que estamos vivendo. Ninguém discute isso. Entretanto é preciso não confundir liberdade com licenciosidade; liberdade com anarquia; liberdade com liberalidade. Diz-se, ainda, comumente, que na democracia cada um tem liberdade de fazer o que bem entende. 'Modus in rebus'. Nunca esquecendo, porém, que um dos postulados consagrados como pedra angular do sistema democrático proclama que o direito de alguém termina onde começa o do próximo. Assim, o indivíduo, nas democracias, é livre para dirigir sua vida no sentido que o deseje, desde que, com isso, não cause danos aos interêsses de seu vizinho; menos ainda, incomparavelmente menos, aos interêsses da coletividade.

"E as nossas observações a respeito do assunto têm por único objetivo prevenir situações irremediáveis, cujas imprevisíveis consequiências para a Nação farse-iam sentir por muito tempo. É uma atitude que assumimos num momento em que mais se faz precisa a coesão da família brasileira para soerguer o combalido organismo nacional, pois é profundamente deprimente que brasileiros andem aí a servir de instrumento de doutrinas importadas. Não se devem esquecer, também, quantos se interessem pelos destinos do regime, que a única coisa que êle não permite é a liberdade de ser destruído." (AINDA A AGITAÇÃO..., 1956, p.1)

A máxima do individualismo burguês "o direito de alguém termina onde começa o do próximo" era levada a primeiro plano na construção do discurso para que o jornal pudesse elevar o indivíduo à condição de classe.

Assim, o "próximo" era a classe onde figuravam os proprietários rurais, e quem estava prejudicando essa classe (trabalhadores rurais guiados pelos comunistas) estava sendo "licencioso".

Posicionando-se ao lado do "próximo" ou "classe" prejudicada, que no caso não eram os trabalhadores rurais e sim os proprietários, a Folha de Londrina dá um caráter social a esse "prejuízo", procurando influenciar a opinião pública a se posicionar contra os comunistas e, consequientemente, contra a classe agressora, que no caso seriam os trabalhadores rurais, organizados pelos comunistas.

A exemplo dos "soldados da produção" de Álvaro Godoi, o editorial da Folha de Londrina conclamava a "família brasileira a se unir numa cruzada contra a doutrina importada", para dessa forma restaurar um "organismo combalido", o país. Por parte de autoridades públicas do Estado, o discurso empregado para legitimar práticas anticomunistas era mais refinado. Tratava-se de declarações menos adjetivadas, menos sensacionalistas, porém não menos estruturadas, de forma a descaracterizar o movimento em questão.

Valendo-se do "bom modelo" de sindicatos para sua análise, o delegado regional do Trabalho, Antônio de Paula Filho, condenava o "sindicato infiltrado de comunistas". Porém, o mais significativo em sua declaração era a pista que dava aos proprietários rurais para ilegalizar a ação mobilizadora do Sindicato dos Colonos e Assalariados Agrícolas.

Em 22 de julho de 1956, passando por Londrina, o delegado apontava uma "falha" dos "comunistas", que seria o principal pretexto dos proprietários rurais para perseguições, denúncias e abertura de inquéritos que norteariam os trabalhos dos anticomunistas e a classe dominante nos meses seguintes:

“informamos os jornais, especialmente a 'Folha' que não tinha consistência jurídica o pretenso 'Sindicato dos Colonos e Assalariados Agrícolas do Norte do Paraná', que não se constitui conforme os preceitos legais que regem a matéria. De fato, só podem funcionar as entidades de classes reconhecidas pelo exmo. sr. ministro do trabalho o que absolutamente não ocorreu com o citado pseudo-sindicato". (PAULA FILHO, 1956, p.1) 
Uma semana depois, a "falha" levantada pelo delegado do Trabalho começava a mostrar resultados. O editorial da Folha de Londrina intitulado "Caso de polícia ou de justiça?", com a mesma estrutura de "bom" e "mau modelo de sindicato", inseria novos questionamentos à ação organizada pelos trabalhadores rurais em torno de sua entidade, que se tornaria fundamento para a entrada de processos na Justiça contra as lideranças sindicais:

"Êsse movimento, pelo que se vem observando, não busca acautelar os legítimos direitos dos sindicalizados; pelo contrário, usando da mentira, da mistificação e de uma interpretação falsa dos dispositivos da legislação social, acena-lhes com absurdas e insustentáveis reivindicações, para melhor levá-los, pela derrota na Justiça, ao desprezo e à revolta." (CASO DE POLÍCIA..., 1956, p.1)

O interessante deste editorial é que, mais do que tentar formalizar a suposta ilegalidade das reivindicações dos trabalhadores e, por conseqüência, os atos das lideranças do sindicato, aconselhava os trabalhadores a se resignar em suas condições de trabalho e esperar que a legislação trabalhista fosse estendida ao campo:

"A legislação trabalhista, como criada e codificada, deixou de fora a condição do operário rural. Foi uma omissão lamentável da Lei, não há dúvida, e que não cabe, aqui discutir.

“Acontece, porém, que a extensão da legislação social para incluir os trabalhadores do campo, é problema grave e complexo, já nas cogitações do Govêrno.

"Até que venha o amparo legal efetivo, os trabalhadores rurais devem eximir-se de reclamações infundadas, de reivindicações de qualquer amparo em dispositivo legal expresso e incontrovertido." (idem)

A Folha de Londrina demonstrava estar bastante empenhada em produzir uma imagem negativa do Sindicato, de forma a desestruturar o movimento, chegando a desestimular a luta por justiça social.

A Folha de Londrina não publicava dados sobre o projeto de lei de extensão da legislação trabalhista aos trabalhadores rurais nem colocava em questão a essência do seu conteúdo. Ela restringia-se a alertar que era necessário ter muito cuidado na discussão e aprovação desta lei para evitar que a "demagogia" pusesse em risco a economia do país.

Os editoriais defendiam que os benefícios sociais deveriam ser os mínimos possíveis, para onerar menos os proprietários rurais:

“Entrou em regime de urgência, na Câmara dos deputados, o projeto de lei que manda estender aos trabalhadores rurais os benefícios da legislação trabalhista. "A medida que se pretende levar a efeito agora, envolve grandes e fundamentais interêsses, não só os das partes nela diretamente envolvidas, como também, o de tôda a Nação.
"Somos um país cuja estrutura econômica depende, consideravelmente, das atividades rurais. Daí o cuidado que exige um estatuto jurídico como o que se pretende disciplinar essa atividade. Qualquer sentido demagógico que se imprimir à lei redundará em prejuízo para a Nação, e conseqüientemente, para as próprias classes que se pretende beneficiar.

"Em matéria de tanta monta, envolvendo a própria estrutura econômica do País, dar pasto à demagogia eleitoreira é pôr em causa, atendendo a razões estranhas, os interêsses superiores da Nação. Antes e acima de tudo, portanto, nessa extensão da lei trabalhista ao homem do campo, há a considerar as exigências fundamentais da estabilidade do próprio regime.

"A legislação social estendida às atividades agrárias demanda um estudo mais acurado do meio que se vai aplicá-la, dada a complexidade da questão e o intrincado dos problemas a que deverá fazer face. Por isso é desaconselhável adotar de modo a orientação empírica e de simples transladação de fórmulas que se p6s em prática, em grande parte, para a feitura das leis de proteção e amparo do trabalhador urbano.

"Não desconhecemos a urgente necessidade de se criar um estatuto jurídico para disciplinar o trabalho rural. Como está é que não é possível continuar. Por falta justamente dêsse estatuto é que a desordem foi tomando conta de nosso campos e o êxodo rural ameaçando levar a uma fatal decadência a nossa agricultura.

“A lei, portanto, irá pôr ordem onde, até agora, vem imperando um estado de quase anarquia.

"Se a legislação social de que se cogita não vier com êsse conteúdo sadio, se deixar envenenar pela peçonha demagógica, grandes serão os males que acarretará ao País.

"Cumpre que em assunto de gravidade inegável, como êsse, se legisle acima das conveniências partidárias, acima do propósito impatriótico de ampliar a clientela eleitoral ou satisfazer simples capricho pessoal. Porque, em não se fazendo assim, estar-se-á, em vez de legislando, preparando terreno para a subversão social." (LEGISLAR SEM SUBVERTER..., 1956, p.1)

A Folha de Londrina propunha que antes que fosse estendida a legislação trabalhista ao campo devia-se fazer a "reforma agrária". O interessante é que, no entendimento do jornal, a reforma agrária era simplesmente um planejamento, por parte do Estado, a respeito da agricultura, e a realização de obras de abastecimento e escoamento dos produtos agrícolas. A Folha sugeria, então, que antes de um estatuto para o trabalhador, devia-se investir em infra-estrutura para os proprietários rurais:

"a primeira consequiência da extensão em massa das leis trabalhistas ao trabalhador rural será a sua absoluta inobservância em quase todo o País. Realmente, antes de se cogitar de melhorar as condições sociais dos trabalhadores, dever-se-ia procurar a melhoria 
da própria agricultura. (...) Não há, portanto, pensar em erguer os níveis sociais do homem do campo sem que se atente, primeiro, para a própria realidade econômica em que êle se encontra. (...) Dotar o trabalhador rural dos direitos e garantias de que goza o trabalhador urbano (...) será pôr em perigo a própria estabilidade econômica da Nação". (PRIMEIRO A REFORMA..., 1956, p.1)

A Folha de Londrina insistia na suposta ilegalidade do Sindicato dos Colonos e Assalariados Agrícolas e que existiriam delitos praticados por comunistas através daquela entidade. Assim figurava uma manchete publicada pelo jornal no dia 10 de agosto de 1956, quando foi feita denúncia de que seis supostos comunistas "extorquiam" dinheiro dos trabalhadores rurais. A denúncia foi feita pelo promotor, Sr. Paulo Ildefonso D'Assunção. (OFERECIDA DENÚNCIA..., 1956, p.1)

A denúncia foi colocada em dois planos. No primeiro, o dinheiro seria recolhido de má-fé e sob ameaças por uma entidade inexistente. No segundo, com o pretexto de manter o "pseudo-sindicato", os comunistas estariam levantando fundos para "comprar armas para uma revolução".

Interessante é que as testemunhas arroladas pela promotoria eram proprietários rurais e pessoas investidas em cargos públicos, não se encontrando entre elas trabalhadores rurais que teriam sido coagidos. A Folha de Londrina deu grande destaque à denúncia, trazendo no mesmo dia uma matéria com o seguinte título: "Seria o norte do Paraná o trampolim da revolução bolchevista no sul do país." (SERIA O NORTE..., 1956, p.5)

Tratava-se de notícia reproduzida do "Diário da Noite" sobre o pronunciamento do senador Otton Mader na tribuna do Senado, pedindo esforços do governo federal para "conter o movimento comunista" no norte do Paraná. O senador "denunciava" a presença, no norte do Paraná, de Gregório Bezerra, militante comunista que estaria organizando a revolução neste estado.

Em uma segunda matéria publicada no mesmo dia pela Folha de Londrina, o senador atribuiu o movimento à tolerância do Ministério do Trabalho, que permitia a sindicalização dos trabalhadores rurais.

Ele dizia ainda, que, em "conseqüência, (...) os trabalhadores do Norte do Paraná já não obedecem mais aos seus patrões, e com isso, está ameaçada de um colapso total a produção cafeeira daquela região." (QUATRO CANTOS..., 1956, p.6)

Sobre a obediência dos trabalhadores rurais aos patrões, Gregório Bezerra, em suas Memórias, tem uma passagem interessante, na qual comenta que em menos de três meses a campanha de sindicalização contava já com $18 \mathrm{mil}$ associados. Segundo ele:

"Com a ajuda dos advogados, começamos a intimar os fazendeiros para comparecerem à Justiça. Os fazendeiros irritados comentavam:

"- A geada não é nada. A geada só mata café novo, de um a dois anos. E o governo indeniza, a gente acaba não perdendo nada. O pior é a praga do comunismo, que, está se alastrando pelo Norte do Paraná. Os sindicatos já estão mandando em tudo, os peões, os colonos e demais trabalhadores não nos respeitam mais, querem discutir de igual para igual com os patrões. Quem já viu semelhante absurdo? Só mesmo uma ditadura militar pra dar jeito nessa baderna!" (BEZERRA, 1980, p.124)

As declarações do delegado do Trabalho na Folha de Londrina sobre ilegalidade da entidade dos trabalhadores rurais, por aproximadamente um mês fez-se presente quotidianamente no jornal, legitimando e incentivando a polícia local a promover constantes "diligências" para apreensão de "materiais de propaganda subversiva" do Sindicato. (REQUERIDA PRISÃO..., 1956, p.6)

A Folha de Londrina deve ter se surpreendido com o desfecho de sua promessa de publicação do despacho do juiz da comarca de Londrina (ROCHA, 1956, p.4) sobre as denúncias feitas pelo promotor público.

Para infelicidade dos fazendeiros, diante das "provas contundentes" de estelionatos praticados por "elementos subversivos" contra os trabalhadores rurais, o juiz rejeitou a denúncia contra os acusados alegando insuficiência de provas e considerando natural o desenvolvimento organizativo da entidade.

Conforme os documentos apresentados na denúncia, constava um convite da entidade, subscrito por um dos acusados, endereçado ao promotor público, Paulo Ildefonso D'Assunção, para que assistisse e tomasse parte nos trabaIhos de uma assembléia geral extraordinária do sindicato.

A informação sobre esse convite não tinha sido publicada pela Folha de Londrina, e mais, o promotor, não tendo participado da tal assembléia, assumia agora papel ridículo diante da opinião pública.

Um outro impresso constante na denúncia convocava os sócios do sindicato para tratarem, entre outros assuntos, de estudar entendimentos com os patrões.

O editorial desse dia identificava o problema dos trabalhadores rurais com o dos proprietários: eles eram vítimas do Estado, que privilegiaria a cidade em detrimento do campo. Nesse editorial não aparece uma única vez o termo comunista ou sindicato subversivo, agentes vermelhos e outras expressões freqüentemente utilizadas.

Alguns dias depois, o promotor Paulo Ildefonso D'Assunção, numa entrevista intitulada "Vítima de ameaças o promotor Paulo Ildefonso D'Assunção", comentava de maneira bastante ressentida o despacho do juiz, e, conforme o título, procurava uma saída honrosa:

"Tenho recebido mesmo ameaça dos vermelhos, mas não abdicarei do cumprimento do meu dever. Sei que êles me odeiam, mas seu ódio não me intimidará, porque não transijo com traidores, com vendiIhões da Pátria, com vis estelionatários que, com artimanhas as mais variadas, vêm explorando humildes trabalhadores rurais, a fim de levar nosso País à fome, ao caos. Felizmente, a opinião pública e os homens de bem desta terra têm servido, a esta Pro- 
motoria, de estímulo na prossecução de seu dever." (D’ASSUNÇÃO, 1956, p.6)

Um dos órgãos criados pelo estado para o desenvolvimento das atividades agrícolas foi a Fundação de Assistência ao Trabalhador Rural (FATR) e, dentre as suas atividades, estava o "combate ao comunismo".

Como órgão do governo do estado, a FATR tinha recursos e mobilidade para o acesso aos trabalhadores rurais em todo o Paraná, com recursos humanos em equipes volantes.

Sobre o "combate ao comunismo", é ilustrativo o "desempenho" desse órgão, publicado pela folha de Londrina em dezembro de 1956 numa grande reportagem sobre suas atividades:

"Um dos problemas com que atualmente luta a Fundação de Assistência ao Trabalhador Rural (...) é o da infiltração comunista no norte do Paraná, com todos os perigos que traz em seu bôjo. Nesse sentido, a Fundação tem procurado, por todos os meios ao seu alcance, adotar medidas visando dar combate ao surto bolchevista que já graves prejuízos tem causado aos fazendeiros, sitiantes, lavradores, etc., e, de conseqüência, com perniciosa repercussão na economia da região, logicamente, na do estado e naturalmente na do País." (APARELHA-SE A FATR..., 1956,p.4)

No mesmo dia a Folha de Londrina publicava o discurso de Álvaro Godoi proferido na Rádio Londrina, desferindo críticas à FATR:

"Li ha dias, um manifesto que está sendo distribuído pelas fazendas que a doutrina dos colonos sôbre direitos que, diz, fazem parte das leis da consolidação do trabalho do homem do campo. Tal manifesto é assinado pelo sr. José Pereira Costa. Entretanto, êsse cidadão, que tanto cuidado demonstra pelos interesses dos colonos, esqueceu-se de esclarecer, na dita publicação, sôbre o destino tomado pelo dinheiro arrancado deles, ruma até agora ignorado segundo soube pelo jornal 'Correio Paranaense', de 19-8-57. "Como é sabido por todos que lêem jornais, a questão de direito dos colonos está sendo discutida na Câmara federal e existe um ante-projeto a respeito. Quanto à demora, não cabe ao lavrador e nem ao colono, mas sim aos nossos legisladores, cujo tempo é empregado em futilidades, viagens ao Estrangeiro, importações rendosas, política, etc. Sôbre a segunda parte do manifesto, o sr. José Pereira da Costa dá uma demonstração gritante de nada entender da vida rural. Ninguém é obrigado a pagar tanto ou quanto; como ninguém é obrigado a aceitar êsse pagamento. Enquanto os capachos comunistas não tomam conta deste grande Brasil, onde pequeno é só o homem." (GODOI, 1957, p.1)

Era realmente marcante o posicionamento dos proprietários rurais: com o intuito de não reconhecer os míni- mos direitos dos trabalhadores, acusavam uma fundação do governo do estado, que fazia campanha anticomunista, de prestar serviço aos comunistas.

A Folha de Londrina, por sua vez, reiterava o discurso da classe dominante local. Era expressão do ideário conservador da elite agrária que dominava na região.

\section{NOTAS}

\begin{abstract}
1 Segundo Marcondes Filho: "O aparecimento do jornalismo ocorre como a forma de afirmação e de imposição de idéias da nova classe, principalmente mais tarde. A atuação social de transmissão noticiosa, que no início ligava-se especificamente à troca de informações sobre mercadorias, sobre o movimento de bolsas, chegada de navios e dados sobre a atividade econômica em geral, só vai encontrar expressão política suficiente no momento em que os comerciantes (capitalistas, então) precisaram agitar a esfera pública para a criação da retaguarda social e ideológica da mudança nos rumos do mundo." (MARCONDES FILHO, 1984, p.15)

2 Afirma MARCONDES FILHO (1986, p.12): "Atuar no jornalismo é uma opção ideológica, ou seja, definir o que vai sair, como, com que destaque e com que favorecimento, corresponde a um ato de seleção e exclusão. Este processo é realizado segundo diversos critérios, que tornam o jornal um veículo de reprodução parcial da realidade. Definir a notícia escolher a angulação, a manchete, a posição na página ou simplesmente não dá-la é um ato de decisão consciente dos próprios jornalistas. É sobre a notícia que se centra o interesse principal no jornalismo."

3 "Tendo ao longo desses anos o personalismo de João Milanez à frente de inúmeras campanhas pelos municípios e por causas filantrópicas, econômicas e políticas, a Folha de Londrina deu primazia, contudo, ao lado econômico, empresarial." (TRIGUEIROS FILHO \& TRIGUEIROS NETO, 1991, p.41)

${ }^{4}$ Sobre o que o jornal noticiava e da característica de cidade nova, Walmor Macarini, diretor de redação da Folha de Londrina, aponta: "Éramos um 'oásis' de pobreza rodeado por ricos de todos os lados. E nós gostávamos de falar da opulência da cidade. Isto era notícia." (apud TRIGUEIROS FILHO \& TRIGUEIROS NETO, 1991, p.65)
\end{abstract}

\section{REFERÊNCIAS BIBLIOGRÁFICAS}

A AGITAÇÃO nos meios rurais. Folha de Londrina. Londrina, 29 jun.1956, cad.1, p.1.

A FÓRMULA milagrosa. Folha de Londrina. Londrina, 17 maio.1956, cad.1, p.1.

AINDA A AGITAÇÃO social. Folha de Londrina. Londrina, 3 jul.1956, cad.1, p.1.

APARELHA-SE A FATR para dar mais assistência ao trabalhador do campo. Folha de Londrina. Londrina, $13 \mathrm{dez} .1956$, cad.2, p.4.

ARGUS. "Ronda pela cidade". Folha de Londrina. Londrina, 20 maio.1956, cad.1, p.10.

BEZERRA, Gregório. Memórias: 1946 a 1969. 2.ed. Rio de Janeiro: Civilização Brasileira, 1980

BORBA, Glauco Pereira. "Todos os dias". Folha de Londrina. Londrina, 15 maio. 1955, cad.1, p.8.

CABRAL, Hugo. "Desorganização, indisciplina e desrespeito nos estabelecimentos agrícolas do Paraná". Folha de Londrina. Londrina, 21 jul.1956, cad.1, p.5.

CAMARGO, Aspásia de Alcântara. "A questão agrária: crise do poder e reformas de base (1930-1964)". In. FAUSTO, Boris. (org.) História geral da civilização brasileira: o Brasil republicano. v.3. São Paulo: Difel, 1983

CARDOSO, Miriam Limoeiro. Ideologia do desenvolvimento: Brasil: J.K.- 
J.Q. 2.ed. Rio de Janeiro: Paz e Terra, 1978.

CASO DE POLÍCIA ou de Justiça?. Folha de Londrina. Londrina, 27 jul.1956, cad.1, p.1.

COLETIVO DE AUTORES "IMPRENSA". "A estrutura de imprensa no presente: fundamentos e formas de atuação no sistema de imprensa da economia privada". In: MARCONDES FILHO, Ciro. (org.). Imprensa e capitalismo. São Paulo: Kairós, 1984. p.41-84.

CRUZ, Adelina Alves Novaes; Célia Maria Leite Costa; Maria Celina Soares D'Araújo et al. (orgs.). Impasse na democracia brasileira 1951/1955: coletânea de documentos. Rio de Janeiro: CPDOC-FGV, 1983

D'ASSUNÇÃO, Paulo Ildefonso. "Vítima de ameaças o promotor Paulo Idefonso D'Assunção". Folha de Londrina. Londrina, 23 ago.1956, cad.1, p.6.

DENÚNCIA DA LAVOURA contra a articulação comunista em Londrina. Folha de Londrina. Londrina, 19 maio.1956, cad.1, p.1.

DISCORRE NA CÂMARA o sr. Hugo Cabral sobre a agitação comunista no norte do Paraná. Folha de Londrina. Londrina, 13 jul.1956, cad.1, p.1.

GODOI, Álvaro. "Quatro cantos, quatro fatos...". Folha de Londrina. Londrina, 23 maio.1956a, cad.1, p.4.

"A agitação e as condições de colonos e patrões têm como causa a política do ministro da Fazenda". Folha de Londrina. Londrina, 3 jun.1956b, cad.2, p.4.

"Nossa associação está vigilante na defesa dos interesses dos que carregam o Brasil às costas". Folha de Londrina. Londrina, 7 set.1957, cad.3, p.1.

LAGE, Nilson. Ideologia e técnica da notícia. Rio de Janeiro: Vozes, 1979.

LAMASTRA, Rafael. "Luta de classes". Folha de Londrina. Londrina, 22 maio.1956, cad.1, p.4.

LEGISLAR SEM SUBVERTER. Folha de Londrina. Londrina, 8 ago.1956, cad.1, p.1

LUZ, Ivan. "A linha". Folha de Londrina. Londrina, 24 nov.1956a, cad.1,p5.

"Com que roupa?!". Folha de Londrina. Londrina, 6 dez.1956b, cad.1, p.5.

MARCONDES FILHO, Ciro. "Imprensa e capitalismo". In: MARCONDES FILHO, Ciro. (org.). Imprensa e capitalismo. São Paulo: Kairós, 1984. p.11-22.

. O capital da notícia: jornalismo como produção social de segunda natureza. São Paulo: Ática, 1986

MARX, Karl \& ENGELS, Friedrich. "A ideologia alemã". In: BARATAMOURA, José; CHITAS, Eduardo; MELO, Francisco et al. Marx, Engels. Obras escolhidas. t.1. Lisboa/Moscovo: Editorial Avante/Edições Progresso, 1982, p.4-74.

NOVAS DENÚNCLAS contra a agitação comunista nos meios rurais. Folha de Londrina. Londrina, 22 maio.1956, cad.1, p.1-10.

OFERECIDA DENÚNCIA por crime de estelionato contra o advogado Flávio Ribeiro e cinco outros líderes comunistas. Folha de Londrina. Londrina, 1 ago.1956, cad.1, p.1.

PAULA FILHO, Antônio. "Fala o delegado do Trabalho sobre a sindicalização rural no norte do Paraná". Folha de Londrina. Londrina, 22 jul.1956, cad.1, p.1.

PRIMEIRO A REFORMA agrária. Folha de Londrina. Londrina, 9 ago.1956, cad.1, p.1.

QUATRO CANTOS, quatro fatos. Folha de Londrina. 1 ago.1956, cad.1, p.6.

REQUERIDA PRISÃO preventiva de dirigentes do sindicato comunista. Folha de Londrina. Londrina, 17 ago.1956, cad.2, p.6

ROCHA, Hércules de Macedo. "Despacha o juiz Hercules de Macedo Rocha denúncia apresentada pelo promotor Paulo Ildefonso D'Assunção contra os comunistas". Folha de Londrina. Londrina, 19 ago.1956, cad.2, p.4.
SERIA O NORTE do Paraná o trampolim da revolução bolchevista no sul do país. Folha de Londrina. Londrina, 10 ago.1956, cad.1, p.5.

SKIDMORE, Thomas. Brasil: de Getúlio à Castelo. 7.ed. Rio de Janeiro: Paz e Terra, 1982.

TRIGUEIROS FILHO, Marinósio \& TRIGUEIROS NETO, Marinósio. História da imprensa de Londrina: do baú do jornalista. Londrina: UEL, 1991. 